\title{
Critic's Choice Essay "SUPPORT YOUR LOCAL HERBARIUM"
}

\author{
Wayne J. Elisens
}

Are herbaria becoming threatened and endangered? Are natural science collections going extinct? These questions are being posed increasingly by amateur and professional biologists as we witness the closure, dispersion, and scaling back of natural history collections and cutbacks affecting curatorial personnel. Noteworthy examples include the elimination of several collections and removal of the herbarium curator at the University of Nebraska State Museum, the transfer of the herbarium collections from the University of Iowa to the herbarium of Iowa State University, and the narrow escape from closure for the University of Arkansas herbarium in Fayetteville. These and other events at various institutions have prompted several recent editorials in the science literature stating that the nation's natural history collections are "in crisis" (Dalton 2003, Gropp 2003, and Raven 2003). What about Oklahoma's herbaria? Should we be concerned about their health and well-being? What can we do? The first thing we can do as natural historians and concerned citizens is to dispel misinformation. For example, herbaria and other natural history collections should not be portrayed as the equivalent of a "stamp collection" (as I heard once from a botanical colleague), but rather as biological research collections. This latter phrase is the foundation for the acronym of the National Science Foundation program (the BRC program) that funds infrastructural improvement and computerization of natural history collections. A herbarium is more than just the physical collection of plants that have been pressed, dried, and stored in packets or mounted on paper of archival quality. Specimens include labels with critical information about the plant's identity, geographic location, ecological habitat, flowering time, and collecting history. Each specimen embodies the species' morphology (its phenotype) AND its genome (its genotype). In other words, each specimen represents valuable DATA and the entire collection should be viewed as a vast data and DNA bank. Oklahoma's herbaria serve as important resources for its citizens and as critical research tools for an international network of scientists, educators, resource managers, and amateur botanists (see Funk 2003).

Thirteen herbaria with combined holdings exceeding 450,000 specimens constitute the "Oklahoma herbarium community" (Table 1). Twelve of these herbaria are listed in Index Herbariorum (Holmgren et al 1990), which is the official international registry of herbaria compiled by the International Association for Plant Taxonomy and the New York Botanical Garden. Each herbarium has noteworthy regional, ecological, and taxonomic specializations. Despite the size and significance of the collections, most of Oklahoma's herbaria are inadequately supported, some have no "hard" budgetary support, most need facility upgrades, and the majority is maintained by the efforts of one or two individuals with limited help from students and a few volunteers. Faculty retirements, budget cuts, and personnel changes make some herbaria "vulnerable." To return to the opening question, some of Oklahoma's herbaria can be categorized as "endangered", because they meet the criterion of possible extinction in the foreseeable future. What is being done to ensure their survivability?

Oklahomans are fortunate to have a highly interactive network of plant taxonomists. More than in most states, plant taxonomists from across Oklahoma have an uncommon sense of collegiality and are collaborating to study the state's flora, to database label information from Oklahoma plant specimens, and to interact with the community of amateur botanists such as those in the ONPS, TNC, etc. Nine botanists representing seven institutions are working to complete a modern flora for the state - the Flora of Oklahoma project. Additionally, botanists at OU and OSU working with their colleagues in the Oklahoma herbarium community are recording label data from Oklahoma plant specimens for the Oklahoma V ascular Plants Database project. Both of these projects draw on collective knowledge, advance the study of Oklahoma's flora, share scientific expertise and resources, and promote the significance of the state's herbarium collections. Despite these positive developments, there are many areas where the public's help is needed to avoid extinctions. 
Herbaria need advocates in both the professional and public arenas. Just as individual curators must promote research and the importance of their collections to administrators and colleagues, amateur botanists both individually and collectively must elevate public awareness of the importance of herbaria. At the University of Arkansas, two events apparently impressed administrators and "saved" the herbarium from closure - the mass response from the professional botanical community and the widespread support throughout Arkansas from amateur botanists and natural historians. Some important lessons from the Arkansas case are the significance of outreach efforts and the reciprocal nature of herbarium activities. In Oklahoma, I am constantly impressed with the number of curators and professional biologists that maintain active public service involvement as officers and board members of organizations and through participation in lectures, field trips, workshops, and other functions. These activities result directly and indirectly from the presence of functioning herbaria located throughout the state and from the actions of knowledgeable professional staff.
In view of the "crisis" impacting natural history collections and herbaria nationwide, I urge amateur botanists to advocate for and to assist herbaria whenever possible. One mechanism to do this is to use the $\boldsymbol{P V C}$ model: Participate in sponsored activities, Volunteer your services, and Communicate your support to others. Oklahoma's herbaria need your help to avoid local or regional extinction. A quick perusal of Table 1 indicates that there is a herbarium located conveniently near you. Support your local herbarium; help preserve our botanical heritage!

\section{LITERATURE CITED}

Dalton, R. 2003. Natural history collections in crisis as funding is slashed. Nature 423: 575 .

Funk, V. A. 2003. The importance of herbaria. Plant Science Bulletin 49(3): 94-95.

Gropp, R. W. 2003. Are university natural science collections going extinct? Bioscience 53:550.

Holmgren, P. K., N. H. Holmgren, and L. C. Barnett (eds.). 1990. Index Herbariorum. Bronx, New York: New York Botanical Garden Press.

Raven, P. H. 2003. Biodiversity and the future. American Scientist 91:382

Table. Approximate numbers of specimens housed in the Oklahoma herbarium community

\begin{tabular}{c}
$\begin{array}{c}\text { Index } \\
\text { Herbariorum } \\
\text { acronym }\end{array}$ \\
Institution and location \\
\hline
\end{tabular}

$\begin{array}{ll}\text { Number } & \text { Number of } \\ \text { of total } & \text { Oklahoma }\end{array}$ specimens specimens

CAMU

CSU

DUR

ECSC

NOSU

NWOSU

OCLA

OKL

OKLA

ORU

TULS

$\mathrm{WOH}$
Cameron University, Lawton

University of Central Oklahoma, Edmond

Southeastern Oklahoma State University, Durant

East Central University, Ada

Northeastern State University, Tahlequah

Northwestern Oklahoma State University, Alva

University of Science \& Arts of Oklahoma, Chickasha

University of Oklahoma, Norman

Oklahoma State University, Stillwater

Oral Roberts University, Tulsa

University of Tulsa

Southwestern Oklahoma State University, Woodward

Oklahoma Panhandle State University, Goodwell

TOTALS

\begin{tabular}{cc}
6000 & 5000 \\
10,000 & 9000 \\
20,000 & 12,000 \\
6000 & 6000 \\
6000 & 5500 \\
5000 & 4000 \\
20,000 & 18,000 \\
210,000 & 150,000 \\
140,000 & 112,000 \\
6000 & 5500 \\
10,000 & 8000 \\
11,000 & 10,000 \\
3000 & 2500 \\
\hline $\mathbf{4 5 3 , 0 0 0}$ & $\mathbf{3 4 7 , 5 0 0}$
\end{tabular}

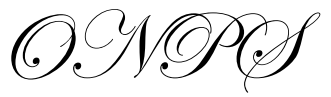

Critic's Choice

Elisens, W.J. 